Kong. Res. J. 4(2): 178-182, 2017

ISSN 2349-2694

Kongunadu Arts and Science College, Coimbatore.

\title{
ALLELOPATHIC INFLUENCE OF CASUARINA EQUISETIFOLIA L. ON GROWTH AND DEVELOPMENT OF RICE (ORYZA SATIVA L.)
}

\author{
Prabhakaran, J*. and K. Arumugam \\ Botany wing - DDE, Annamalai University, Annamalai Nagar - 608 002, Tamil Nadu, India. \\ *E.mail: drprabha2006@gmail.com
}

\begin{abstract}
Leaf extracts of Casuarina. equisetifolia L. was evaluated for its allelopathic influenced on rice cultivars viz. IR- 20 and TKM - 9. Leaf extracts was tested at 2.5, 5, 10, 15 and 20\% concentration. Seed germination, shoot length, biomass, chl - a , chl- b, carotenoids, starch, protein and amino acid contents were significantly reduced by leaf extracts and highest inhibition was observed in $20 \%$ concentration. But at lower concentration $(2.5 \%)$, the seedling growth was slightly enhanced than control. The higher degree of germination and growth inhibition was observed in cultivar TKM-9 than IR-20.
\end{abstract}

Keywords: Allelopathy, Casuarina equisetifolia, rice cultivars.

\section{INTRODUCTION}

Agroforestry is the integration of
Agriculture and forestry to increase
the farm productivity and sustainability of farming system. Casuarina equisetifolia L. is a commonly grown in coastal regions of Tamil Nadu. It is an evergreen tree fixing atmospheric nitrogen and sheds the needles at maturity. Plants compete with each other for light, water and nutrients. Whenever two or more plants occupy the same niche in nature, they compete with each other for various life support requirements (Caton et al., 1999). Production of secondary metabolites, accumulation and release of these compounds is one of several complex defense strategies that have evolved by plants (Rice, 1984; Swain,1977). There are hundreds of secondary metabolites in the plant kingdom and many are known to be phytotoxic (EINHELLING, 2002). The interaction of plants through release of chemical is called allelopathy and it includes both positive and negative effects of one plant on the other.

In agro ecosystems several weeds, crops, agro forestry trees and fruit trees have been shown to exact allelopathic influence on the crops, thus, affecting their germination and growth adversely (Kohli et al., 1998). The chemical interaction of plants through chemical signals or allelopathy has many possible agricultural applications and decline in crop yields in cropping and agro-forestry decades systems in recent years has been attributed to allelopathic effects. Allelochemicals were reported to be highest in the foliage of many plants; these chemicals were found to be released into the soil system through volatilization, root exudation and leaching from the foliage (Fisher, 1980). Systematic research approach in allelopathy was started only recently in the last two decades and allelopathic influence of multipurpose tree species on crops are being investigated under different agro-eco systems. Hence, this investigation was carried out to study the allelopathic potential of Casuarina equisetifolia leaf extracts on two rice cultivars viz. IR-20 and TKM- 9.

\section{MATERIALS AND METHODS}

The two varieties of Rice seeds such as IR20 and TKM-9 were obtained from Tamil Nadu Agricultural University, Coimbatore, Tamil nadu. To prepare aqueous extracts, $200 \mathrm{~g}$ dried powdered needles of C. equisetifolia were soaked in $1000 \mathrm{ml}$ water in a flask for $48 \mathrm{~h}$ at room temperature $\left(30 \pm 2^{\circ} \mathrm{C}\right)$.Then filtered through Whatman No.1 filter paper. These extracts were of $20 \%$ concentration and further diluted to $2.5,5,15$ and $20 \%$ concentrations. 25 seeds of IR-20, TKM-9 were treated with $0.1 \%$ mercuric chloride, washed thrice with distilled water and dried on an absorbent to eliminate fungal attack then sown in $20 \mathrm{~cm}$ diameter pot containing normal garden soil. Tap water used as control. Different concentrations of extracts or tap water were added as per the treatment in alternative days up to 12 DAS. Germination percentage, plumule length, radical length and seedling dry weight and fresh weight, Pigment contents Chl- a, chl-b, (Arnon,1949), carotenoids (Kirk and Allen, 1965), starch (Clegg, 1956), protein (Lowry et al., 1951) and amino acid (Moore and Stein, 1948) contents were estimated on 12 days old seedlings of rice cultivars. The data was statistically analysed by ANOVA followed by Tuke's Multiple Range Test (TMRT) at $\mathrm{P}<0.5 \%$ level. 


\section{RESULTS AND DISCUSSION}

C. equisetifolia leaf extracts decreased the germination (\%) of rice cultivars IR-20 and TKM-9 (Table 1 and Fig. 1). The per cent reduction over control in the rice cultivars with different concentration of leaf extracts was maximum in TKM9 (58.3\%) than IR- 20 (46.9\%). Among the concentration, maximum inhibition was observed in $20 \%$ followed by $15,10,5$ and $2.5 \%$ (Table 1 ). The different leaf extracts of $C$. equisetifolia significantly decreased the germination. The inhibition of germination is dependent on the concentration of the extracts; perhaps it may be due to the entry of water soluble allelochemicals from the leaf of $C$. equisetifolia. Similar response of sorghum and sunflower exhibited to the extracts of $C$. equisetifolia leaf leachates (Singh, 1993; Suresh,and Vinaya Rai, 1987). The allelopathic compounds in soil come in contact with the roots of tested plant and may alter its absorption capacity for water and minerals, cell division and other physiological functions (Majeed et al., 2012).

Nandal et al. (2005) reported the aqueous extracts of poplar leaves adversely affected the germination and seedling growth of some wheat varieties at high extract concentration. The chemicals have harmful effects on the crop in the eco-system resulting in the reduction and delaying of germination, mortality of seedlings and reduction in growth and yield (Mcworthier, 1984; Herro and Callaway, 2003).

At lower concentration of (2.5\%) C.equisetifolia leaf extracts enhanced the seedling growth of both IR -20 and TKM-9 but at higher levels $(5,10,15$ and $20 \%)$ inhibit the seedling growth (Table- 1). At $20 \%$ extract concentration the fresh weight decrease was in $53.6 \%$ in IR-20 and $57.7 \%$ in TKM-9. The variety, TKM-9 was found to be most sensitive than IR -20. Similar works on leaf leachates of C. equisetifolia significantly decreased the germination, plumule and radicle growth of rice and cowpea (Jadhav and Gaynar, 1995). The study of Umarani and Selvaraj (1996) showed that the stem and whole plant extract of Trianthema portulacastrum reduced the dry matter production on soybean. Beres and Kazinczi (2000) reported that the aqueous shoot extract of Rumex obtusifolius and Asclepias syriaca reduced the fresh and dry weight of corn. June (1976) reported the presence of phytotoxins, phenolics, terpenoides and organic cyamides in Casuarina extracts that cause allelopathic effect. Similarly, Jacob and Nair (1999) reported inhibitory effect of Casuarina leaf extracts on germination, plumule and radicle growth in rice and cowpea. This reduction in seedling growth and biomass may be due to imbalances in water uptake or osmotic balances of the tissues because of allelochemical toxicity (Blum et al., 1999) and or root growth inhibition (Chon et al., 2002). Chon et al. (2002) mentioned that some plants root tip growth nearly inhibited to escape from allelochemicals absorption. Nevertheless, Sing et al., (2003) found that aqueous leaf leachates of Eucalyptus citriodora inhibited seed germination and seedling growth of Vigna Species and elongation of plumule more suppressed than radicles. The aqueous extracts of seeds, leaf, root of Ageratum conyzoides decreased the root and shoot elongation in chickpea (Angiras et al., 1988). Aqueous extract of some plants inhibit seedling growth (Athanassova, 1996), root and shoot growth (Das and Bandyopadhyay, 2011).

Chlorophyll a, b and Carotenoids contents were increased at both test crops at lower concentration of $(2.5 \%)$ of leaf extracts (Table 2). But at $20 \%$ chlorophyll a was reduced by $48.3 \%$ and $53.0 \%$ and Chlorophyll b was reduced by $54.3 \%$ and $56.4 \%$ respectively, in TKM-9 and IR-20. In the test crops, IR-20 and TKM-9 was showed a maximum decrease of chlorophyll $b$ than chlorophyll a. The reduction in chlorophyll contents observed in all the concentrations might be due to the degradation of chlorophyll pigments or reduction in their synthesis and the action of flavonoids, terpenoids or other phytochemicals present in the leaf extracts (Tripathi et al., 1999; 2000). The more reduction of chlorophyll $b$ than chlorophyll $a$, indicated its susceptibility to stress (Djanaguiraman et al., 2003). During stress situation, in tolerant species conversion of chlorophyll $b$ to chlorophyll a may occur (Djanaguiraman et al., 2003). Carotenoids may decrease the photosynthesis and thereby substantially decrease all the metabolities viz., total sugars, proteins and soluble amino acids (Singh and Rao, 2003). Reduction in pigments was previously reported as a result of allelochemical stress (Ervin and Wetzel,2000; Moradshahi et al., 2003; Singh et al., 2009). A correlation between photosynthetic alternation and the action of some allelochemical compounds was shown in previous works (Einhellig, 1986; Heji et al., 1993) being the disruption of electron transport chain one of the most usual ways for affecting photosyntheisis by allelochemical compounds (Nimbal et al., 1996 and Gonzelz et al., 1998). 
Table 1. Effect of Casuarina equisetifolia leaf extracts on germination \%(G.\%), plumule length (P.L.), radicle length (R.L.), fresh weight (F.Wt.) and dry weight (D.Wt.) of two Rice cultivars.

\begin{tabular}{ccccccccccc}
\hline \begin{tabular}{c} 
Extract $\begin{array}{c}\text { IR-20 } \\
\text { Conc. }\end{array}$ \\
\cline { 2 - 11 }
\end{tabular} & $\mathbf{G . ~ \%}$ & P.L. & R.L. & F.Wt. & D.Wt. & G.\% & P.L. & R.L. & F.Wt. & D.Wt. \\
\hline $\mathbf{C}$ & 98 & 6.63 & 3.58 & 98.60 & 32.19 & 96 & 6.55 & 3.60 & 99.60 & 33.12 \\
$\mathbf{2 . 5}$ & 100 & 6.79 & 3.69 & 98.90 & 32.40 & 98 & 6.78 & 3.74 & 99.85 & 33.34 \\
& $(2.0)$ & $(2.4)$ & $(3.1)$ & $(0.3)$ & $(0.7)$ & $(2.1)$ & $(3.5)$ & $(3.9)$ & $(0.3)$ & $(0.7)$ \\
$\mathbf{5}$ & 96 & 6.12 & 3.36 & 90.12 & 30.14 & 90 & 5.83 & 3.20 & 87.12 & 25.09 \\
& $(-2.0)$ & $(-7.7)$ & $(-6.1)$ & $(-8.6)$ & $(-6.4)$ & $(-6.3)$ & $(-11.0)$ & $(-11.1)$ & $(-12.5)$ & $(-8.7)$ \\
$\mathbf{1 0}$ & 82 & 5.55 & 2.85 & 80.48 & 25.85 & 78 & 5.10 & 2.65 & 76.12 & 21.28 \\
& $(-16.9)$ & $(-16.3)$ & $(-20.4)$ & $(-18.4)$ & $(-19.7)$ & $(-18.8)$ & $(-22.1)$ & $(-26.4)$ & $(-23.6)$ & $(-20.1)$ \\
$\mathbf{1 5}$ & 69 & 4.57 & 2.21 & 65.89 & 20.61 & 60 & 4.30 & 1.98 & 64.65 & 18.85 \\
& $(-29.6)$ & $(-31.1)$ & $(-38.3)$ & $(-33.2)$ & $(-36.0)$ & $(-37.5)$ & $(-34.4)$ & $(45.0)$ & $(-37.1)$ & $(-39.4)$ \\
$\mathbf{2 0}$ & 52 & 3.37 & 1.55 & 45.76 & 13.79 & 40 & 2.99 & 1.27 & 42.13 & 2.96 \\
& $(-46.9)$ & $(-49.2)$ & $(-56.7)$ & $(-53.6)$ & $(-57.2)$ & $(-58.3)$ & $(-54.4)$ & $(-64.7)$ & $(-57.7)$ & $(-60.3)$ \\
\hline
\end{tabular}

Data in parenthesis indicates $\%$ increase $(+)$, decrease $(-)$ over control.

Table 2. Allelopathic effect of C.equisetifolia leaf extracts on pigments (Chlorophyll a, $b$ and Carotenoid contents (mg/g.fr.wt.)) of Rice cultivars

\begin{tabular}{ccccccc}
\hline $\begin{array}{c}\text { Extracts } \\
\text { Concentrations } \\
(\%)\end{array}$ & Chl. a & Chl. b & Carotenoids & Chl. a & Chl. b & Carotenoids \\
\cline { 2 - 6 } & 1.45 & 1.05 & 0.84 & 1.51 & 1.10 & 0.70 \\
Control & 1.64 & 1.17 & 0.93 & 1.70 & 1.20 & 0.76 \\
$\mathbf{2 . 5}$ & $(13.1)$ & $(11.4)$ & $(10.7)$ & $(12.6)$ & $(9.1)$ & $(8.6)$ \\
& 1.34 & 0.95 & 0.74 & 1.37 & 0.97 & 0.61 \\
$\mathbf{5}$ & $(-7.6)$ & $(-9.5)$ & $(-11.9)$ & $(-9.3)$ & $(-11.8)$ & $(-12.9)$ \\
& 1.19 & 0.85 & 0.65 & 1.18 & 0.85 & 0.53 \\
$\mathbf{1 0}$ & $(-17.9)$ & $(-19.0)$ & $(-22.6)$ & $(-21.9)$ & $(-22.7)$ & $(-24.3)$ \\
& 0.99 & 0.69 & 0.53 & 0.99 & 0.69 & 0.43 \\
$\mathbf{1 5}$ & $(-31.7)$ & $(-34.3)$ & $(-36.9)$ & $(-34.4)$ & $(-37.1)$ & $(-38.6)$ \\
& 0.75 & 0.48 & 0.37 & 0.71 & 0.48 & 0.29 \\
$\mathbf{2 0}$ & $(-48.3)$ & $(-54.3)$ & $(-56.0)$ & $(-53.0)$ & $(-56.4)$ & $(-58.6)$ \\
\hline
\end{tabular}

Data in parenthesis indicates $\%$ increase $(+)$, decrease $(-)$ over control.

Table 3. Allelopathic effect of $C$. equisetifolia leaf extracts on Starch, protein and Amino acid contents (mg/g.fr.wt.) of Rice cultivars

\begin{tabular}{ccccccc}
\hline $\begin{array}{c}\text { Extracts } \\
\begin{array}{c}\text { Concentrations } \\
\text { (\%) }\end{array}\end{array}$ & Starch & Protein & $\begin{array}{c}\text { Amino } \\
\text { acids }\end{array}$ & Starch & Protein & $\begin{array}{c}\text { Amino } \\
\text { acids }\end{array}$ \\
\cline { 2 - 7 } Control & 5.20 & 2.28 & 1.54 & 5.35 & 2.47 & 1.58 \\
& 5.49 & 2.40 & 1.61 & 5.61 & 2.57 & 1.64 \\
& $(5.6)$ & $(5.3)$ & $(4.5)$ & $(4.9)$ & $(4.0)$ & $(3.8)$ \\
& 4.96 & 2.13 & 1.40 & 5.08 & 2.26 & 1.37 \\
& $(-4.6)$ & $(-6.6)$ & $(-9.1)$ & $(-5.0)$ & $(-8.5)$ & $(-13.3)$ \\
$\mathbf{1 n}$ & 4.30 & 1.74 & 1.16 & 4.36 & 1.87 & 1.15 \\
& $(-17.3)$ & $(-23.7)$ & $(-24.7)$ & $(-18.5)$ & $(-24.3)$ & $(-27.2)$ \\
$\mathbf{1 5}$ & 3.47 & 1.44 & 0.94 & 3.44 & 1.47 & 0.92 \\
& $(-33.3)$ & $(-36.8)$ & $(-39.0)$ & $(-35.7)$ & $(-40.5)$ & $(-41.8)$ \\
$\mathbf{T n}$ & 2.60 & 1.09 & 0.63 & 2.49 & 0.99 & 0.57 \\
& $(-50.0)$ & $(-52.2)$ & $(-59.1)$ & $(-53.7)$ & $(-59.9)$ & $(-63.9)$ \\
\hline
\end{tabular}

Data in parenthesis indicates \% increase $(+)$, decrease $(-)$ over control. 
The biochemical constituents i.e. starch, protein and amino acid contents showed the same trend like pigments contents of rice seedlings (Table3 ). The $20 \%$ of leaf exract concentration had more inhibitory effect on starch (50\% and $53.7 \%)$, protein (52.2\% and 59.9\%) and amino acid (59.1\% and 63.9\%) contents respectively for IR-20 and TKM- 9 over control. The application of aerial or root biomass of Rhamnus virgattus tree significantly decreased the starch content in Triticum aestivum, Eleusine coracana, Lens culinaris and Phaseolus mungo as compared to control (Prasad et al., 1999). The leaf extract of Populus deltoides reduced protein content in three varieties of green gram (Mandal et al., 2005). Tripathi et al., (1998) studied the allelopathic activity of Tectona grandis, Albizia procera and Acacia nilotica on starch, protein and amino acid contents of soy bean. Leaf extracts of all the three species at the lower concentration showed stimulated effect and at the higher concentration showed the inhibited effect on biochemical constituents (starch, protein and amino acid) in the soybean. These studies are in conformity with the present findings.

Fig 1. Germination $\%$ of two Rice cultivars against the Casuarina equisetifolia leaf extracts treatments.

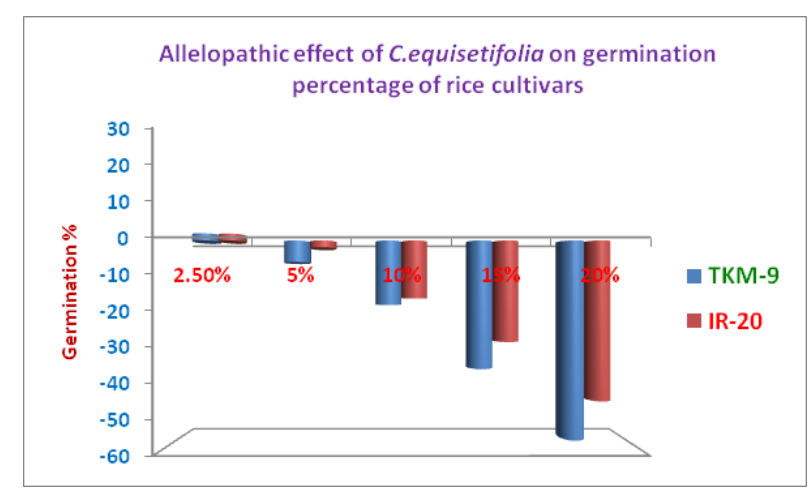

Based on the results it can be concluded that allelopathy is a concentration dependent phenomenon, as the concentration of the $C$. equisetifolia leaf extracts increases, its effect also increases . But at lower concentration (2.5\%) of leaf extracts showed promotory effects on all the studied parameters in both the test crops.. In general the inhibitory effect was observed more in TKM-9 than IR- 20. The negative allelopathic effects of $C$. equisetifolia on IR- 20 and TKM-9 may be due to the presence of allelo chemicals in the extracts, particularly phenolics and other secondary metabolites like growth regulators, alkaloids, terpenoids, organic cyanides and toxins which are reported by June, (1976). However, further studies required to identify the specific phytochemical of $C$. equisetifolia and their allelopathic actions on crop growth under field study.

\section{References}

Angiras, N.N., S.D. Singh and C.M. Singh, (1988). Allelopathic effects of some weeds on germination and growth of chick pea. Ind. J. Weed Sci 20: 85-87.

Athanassova, D.P. (1996). Allelopathic effect of Amaranthus retroflexus $\mathrm{L}$. on weeds and crops. Seisieme Conterence ducoluma. Journees Internationales $\mathrm{Sr}$ La Luttr contre lesmauviases herbs, Reims, France. 437-442.

Beres, I. and G. Kazinczi, (2000). Allelopathic effects of shoot extracts and residues of weeds on crosps. Allelopathic J 7: 93-98.

Blum.U, R. Shafer and M.E. Lemon. 1999. Evidence for inhibitory allelopathic inter action including phenolic acids in field soils: Concept Vs An experimental model.

Caton, B.P., A.M. Mortimer, T.C. Hill, J.E. Gibson and A.J. Fisher, (1999). Weed morphology effects on competitiveness for light in direct - seeded rice. Proc. 17th Asian-Pacific, weed sci., Soc. Conf., Bangkok 1.A, 116-120.

Chon. S.U., S.K. Choi, S.D. Jung, B.S, Pyo and M. Kims, (2002). Effects of alfalfa leaf extracts and phenolic allelochemicals on early seedling growth and root morphology of alfalfa and barnyard grass. Crop Pro 5: 1077-1082.

Das, C. and A. Bandyopadhyay, (2011). Searching for allelopathic potential of Shorea robusta Gaertn.f. leaf. Bionature 31: 29-35.

Djanaguiraman, M., A. Senthil and Ramadass, (2003). Assessment of rice genotypes for salinity tolerance at germination and seedling stage. Madras Agri. J 90: 506-10.

Einhellig, F.A. (1986). Mechanisms and modes of action of allelochemicals. "The Sciences of Allelopathy" (eds.): P.R. Putnam and C.S. Tang. Pp. 171-188. Wiley Inter Science, New York.

Einhellig. F.A. (2002). The physiology of allele chemical action: clues and views. In: Allelopathy, from molecules to Ecosystems. M.J. Reigosa and N. Pedrol, (eds.),: Science publishers, Enfield, New Hampshire.

Ervin, G.N. and R.G. Wetzel, (2000). Allelochemical autotoxicity in the emergent wetland macrophyte Juncus effuses (Jncaceae). Am. J. Bot 87: 853-860. 
Fisher. R.F. (1980). Allelopathy: A potential cause of regeneration failure. J. Forestry 78: 346 -349.

Gonalez, V.M., J. Kazimir, C. Nimbal, L.A. Weston and G.M. Cheniac, (1998). Inhibition of a photosystem II electron transfer reaction by sorgoleone, a natural product. J. Agricul. Food Chem 45: 1415-1521.

Hejl, A.M., F.A. Einhellig and J.A. Rasmussen, (1993). Effects of juglone on growth, photosynthesis and respiration. J. Chem. Ecology 19: 559-568.

Herro, J.L. and R.M. Callaway, (2003). Allelopathy and exotic plant invasion. Plant and Soil 256: 29-39.

Jacob. J. and A.M. Nair, (1999). Allelopathic effect of leaf leachates of multipurpose trees. Allelopathy J 6(1): 81-86.

Jadhav, B.B. and D.G. Gaynar, (1995). Effect of Casuarina equisetifolia J.R. leaf litter leachates on germination and seedling growth of ric and cowpea. Allelopathy J 2: 105-108.

June, S.R. (1976). Investigation on allelopathy in a red leach forest. Mauri Ora 4: 87-91.

Majeed, A., Z. Chaudhry and Z. Muhammad, (2012). Allelopathic assessment of fresh aquesous extracts of Chenopodium album L., for growth and yield of wheat (Triticum aestivum L.).Pak.J.Bot., 44 (1): 165-167.

Mandal, M.P., Das, D.K and Singh, A.K., 2005. Impact of leaf extract of Populus deltoids Marsh. On germination and seedling growth of green gram (Vigna radiate L.). Allelopathy J. 16(2): 317-322.

Mcwhorter, C.G. (1984). Future needs in weed science. Weed Sci 32: 850-855.

Moradshahi, A., H. Ghadiri and F. Ebarhimikia, (2003). Allelopathic effects of crude volatile oil and aqueous extracts of Eucalyptus camaldulensis Dehnh. Leaves on crops and weeds. Allelopathy J 12: 189-196.

Nandal and A. Dhillon, (1999). Allelopathic effects of poplar (populous deltoids Bartr Ex Marsh): an assessment on the response of wheat varieties under laboratory and field conditions. Proceedings of the Fourth World Congress on Allelopathy 21-26 August 2005, Charles Sturt Univ., Wagga Wagga, NSW, Australia.
Nimbal, C.L., L.A. Weston, C.N. Yerkes and S.C. Weller, (1996). Herbicidal activity and site of action of the natural product sorgeolone. ProceedingsWeed Science Society of America 36-56.

Prasad, D., G. Plant and M.S.M. Rawat, (1999). Phytotoxicity of Rhamnus virgatus on some field crops. Allelopathy J 6: 227-242.

Rice, E.I. (1984). Allelopathy second edition. Oriando, Florida: Academic press; p: 442.

Kohli, R.K., D.R. Batish and H.P. Singh, (1998). Euclayptus oils for the control of parthenium hysterophorus L. Crop Prot 17: 9-122.

Sing, D and Y.B. Rao, (2003). Allelopathic evaluation of Andrographis paniculata aqueous leachates on rice (Oryza sativa L.). Allelopathy J 11: 71-6

Singh, A., D. Singh and N. Singh, (2009). Allelochemical stress produced by aqueous leachate of Nicotinana plumbaginifolia. Plant Growth Regul 58: 163-178.

Singh. H.K. (1993). Allelopathic effect of tree species on crop plants. In proceedings and Recommendations of National Work Shop on Farm Farm Forestry management (Eds., T.H. Badu). Pp. 18-22. Bhopal: Indian Institute of forest Management.

Suresh, K.K. and R.S. Vinaya Rai, (1987). Studies on the allelopathic effects of some agroforestry trees on crops. Int. Tree Crop J 4: 109-115.

Swain. T. (1977). Secondary compounds as protective agents. Ann. Rev. Plant Physiol 28: 479-501.

Tripathi, S., A. Tripathi and D.C. Kori, (1999). Allelopathic evaluation of Tectona grandis leaf, root and soil aqueous extracts on Soya bean. Indian J. For 22: 366- 74.

Tripathi, S., A. Tripathi, D.C. Kori and S. Tiwari, (1998). Effect of tree leaves aqueous extracts on germination and seedlings growth of soybean. Allelopathy J 5(1): 75-82.

Tripathi, S., A. Tripathi, D.C. Kori and S. Paroha, (2000). The effect of Dalbergia sisso extracts, rhizobium and nitrogen on germination growth and yield of Vigna radiata. Allelopathy J 7: 25563.

Umarani, R. and J.A. Selvaraj, (1996). Effect of Trianthema portulacastrum on Soybean. Allelopathy J 3: 261-266. 